\title{
An Investigation of the Long-Run and Causal Relationships between Economy Performance, Investment and Port Sector Productivity in Cote d'Ivoire
}

\author{
China Flora Carine Anguibi \\ School of Economics and Management, Shanghai Maritime University, Shanghai, China \\ Email: anguibicarine@hotmail.com
}

Received 25 February 2015; accepted 28 March 2015; published 31 March 2015

Copyright (C) 2015 by author and Scientific Research Publishing Inc.

This work is licensed under the Creative Commons Attribution International License (CC BY). http://creativecommons.org/licenses/by/4.0/

(c) (i) Open Access

\section{Abstract}

This study used the Autoregressive Distributed Lag (ARDL) Bounds testing approach and TodaYamamoto Non-granger causality test to analyze respectively the long-run and causal relationships among economy performance, foreign direct investment, domestic investment and port sector production output in Cote d'Ivoire over the period 1980-2013. The empirical results illustrate that economy performance, foreign direct investment and domestic investment are significant in explaining the productivity of port sector. Therefore, the study suggests focusing on investment strategies that involve private (foreign and domestic) participation in projects dedicated to improve the safety, quality of operations in the sector and transport connectivity.

\section{Keywords}

Port Productivity, Economy Performance, Foreign Direct Investment, Domestic Investment, ARDL Approach, Toda-Yamamoto Causality Test

\section{Introduction}

By connecting sea and land transport for the shipment of commodities in huge quantities at lower cost all over the world, port plays a crucial role in promoting national economy. Transport infrastructure in general influences the growth of the economy [1]. For instance, in case of inadequate infrastructures in port sector, its supply capacity would fail to meet the demand from the economy [2]. Indeed, bottlenecks and delays due to the poor conditions of the sector infrastructures would hinder the activities of the other sectors and negatively affect the 
economy productivity. On the other hand, effective transport infrastructures reduce congestion and have multiplier effects on development. Seaport represents an important industrial and commercial tool for maritime countries economic growth. It provides employment and revenue for government and businesses [3]. In Cote d'Ivoire, more than $91 \%$ of the volume of trade is carried by sea and more than $70 \%$ represents the industrial [4]. Furthermore, Ivorian port contributed to more than $85 \%$ of the customs taxes collections [4]. Accordingly, port is expected to be a strategic tool of growth for the country economy.

Many empirical studies that specifically explore the relationship between port and economy growth have been done. In developed countries, researchers [5] pointed out that port activities not only connect maritime countries but have multiplier effects on the economy by increasing employment for the local population, tax revenues for the local government and stimulating the other sectors of the economy. Conversely, scholars [6] and [7] suggested that regional economy performance has an impact on port productivity. For example, exploring the relationship between port throughput and economic activities using data from Antwerp (Belgium) port sector, researchers [7] discovered that Belgium economy performance as well as that of their hinterland countries has a great influence on port production output. A study based on a pooled-OLS (Ordinary Least Square) model in Germany, proved that port productivity output is positively associated with regional per capita GDP (Gross Domestic Product), however the causality running from port to GDP has not been established [8]. From these studies a cause and effect relationship between port and economic performance is observed in both directions. In other words, port plays a crucial role in promoting the economy growth, while the economic performance of the maritime country or region is believed to be a catalyst for the growth of port sector.

Although, the existence of linkage between port productivity and economy performance has been recognized in the scientific debate, the exact impact relationship is still unclear and influenced by many relevant factors. It is believed that investment and economy performance contribute to sustain port productivity [9]. Hence, investment has to be included in port productivity analysis to gain better understanding of the interplay between seaport production and economy performance. Measuring the impact of long dock investment to economy growth, the researchers [10] found that adding $1 \%$ to the cargo loaded capacity lead to about $0.413 \%$ increase in economy productivity. Thus, investment has contributed to the growth of port capacity which led to the economy growth. By utilizing a Cobb-Douglass production function to model the relationship between port, foreign direct investment (FDI) and economy growth in China, scholars [11] demonstrated that FDI and gross product value of industry have contributed to promote the container throughput of Shenzhen and Guangzhou Ports. Similarly, researchers [12] considering port activities as economic production and economy growth, labor force, foreign direct investment and fixed assets investment as factors of production built port production function. The regression analysis carried, revealed that both economy growth and labor force have a significant impact on port productivity while the effects of fixed asset investment and FDI have been found of low significance.

The poor conditions of port sector in Africa and particularly in Cote d'Ivoire require massive investment on infrastructures in order to cope with the growing demand of the upcoming economy growth [13]. In Nigeria, the report of [14] on FDI inflows has revealed foreign direct investment as a prominent form of investment and an attractive policy option in African port sector. The successful experience of FDI inflows in Nigeria port infrastructures confirmed the positive effect of FDI on transport infrastructure development. In addition, analyzing the impact of FDI on the production of manufacturing firms, researcher [15] sustained that foreign enterprises are more competitive than the domestic firms. An investigation conducted in Venezuelan firms proved the positive correlation between FDI and the productivity of foreign companies whereas it has been found negatively correlated to the performance of the domestic firms in the same industry [16]. Using Vector Error Correction Model, Scholars [17] demonstrated that domestic investment in transport infrastructure will lead to the growth of the Indian economy. These findings imply that investment in port sector using foreign capital is a strategic tool to enhance productivity.

The relationship between port, economy growth and investment has gained a growing interest in the scientific discussion. In contrast, empirical studies exploring the impact of economy performance, foreign direct investment and domestic investment on port productivity in developing countries are to our knowledge limited. Furthermore, past investigation evidenced conflicted results related to many factors such as the capability of the country in enabling economic development, the difference in the quality levels of transport infrastructure, the difference in methodology and data used [18]. Hence, performed this study can provide insight into the role played by economy performance, foreign direct investment and domestic investment in promoting port sector growth in Ivorian context and fill the gap in the literature. The paper is organized into five sections. The next 
section two and three describe the data, model specification and the methodology adopted, respectively. Section four reports the empirical results, while the last section concludes the paper.

\section{Data Description and Model Specification}

\subsection{Data Description}

This study explores the long-run and causal relationships between port, economy performance foreign direct investment (FDI) and Domestic investment (DI) using Cote d'Ivoire annual time series data over the period 1980-2013. Port production (PP) is captured by Port throughput whereas Real Gross Domestic Product (GDP) is the proxy for economy performance. FDI is the value of real gross foreign direct investment inflows and Domestic investment (DI) is proxy by the real value of gross fixed capital formation. Labor (L) measured in terms of labor force. DUM is the dummy variable used to capture the effect of political instability. The data are collected from World Development Indicator, except port throughput obtained from the department of statistics of Ivorian ports.

\subsection{Model Specification}

In order to assess the effects of economy performance, foreign direct investment and domestic investment on port productivity, the study employs three factors aggregate production function to build port production model. The standard form of the three factors production function can be expressed as:

$$
Y_{t}=A_{t} f\left(K_{t}, L_{t}, D_{t}\right)
$$

where $Y_{t}$ denotes the aggregate production of port sector at time $t$, and $A_{t}, K_{t}, L_{t}$ and $D_{t}$ denote the total factor productivity, the capital input, the labor input and the land input in the sector in period t respectively. Following the approach proposed by [12], it is assumed that economy performance; foreign direct investment and domestic investment are factors affecting port production. The performance of the economy represents the capital factor whereas both foreign investment and domestic investment are used to capture land input. Accordingly, we modeled the following port production function as:

$$
P P_{t}=A_{t} f\left(G D P_{t}, L_{t}, F D I_{t}, D I_{t}\right)
$$

Equation (2) can be developed as:

$$
P P_{t}=A_{t} G D P_{t}^{\alpha} L_{t}^{\beta} F D I_{t}^{\eta} D I_{t}^{\lambda}
$$

A dummy variable DUM has been included in the model to capture the political instability. The value is 1 in the year of the instability and 0 otherwise. Thus, Equation (3) becomes:

$$
P P_{t}=A_{t} G D P_{t}^{\alpha} L_{t}^{\beta} F D I_{t}^{\eta} D I_{t}^{\lambda} D U M_{t}^{\delta}
$$

By taking the natural logs of both sides, an estimable function is obtained as follows:

$$
\ln P P_{t}=a+\alpha \ln G D P_{t}+\beta \ln L_{t}+\eta \ln F D I_{t}+\lambda \ln D I_{t}+\delta D U M_{t}+\varepsilon_{t}
$$

where all variables and coefficients are defined as earlier. $a$ is a constant parameter and $\varepsilon_{t}$ the white noise error term.

\section{Methodology}

\subsection{Cointegration Test}

The Autoregressive Distributed Lag (ARDL) bounds testing procedure based on F test is used to examine the long-run relationship among port production output, economy performance, foreign direct investment and domestic investment. The model developed by [19] has many advantages over the conventional multivariate cointegration method such as maximum likelihood cointegration procedures introduced by [20]. One of the main advantages is that the bounds testing methodology can be applied irrespective of whether the regressors are stationary at level (I(0)) or integrated of order one (I(1)) and does not involve unit-root pre-testing for the variables [19]. Nevertheless, it requires testing the stationarity of the variables to ensure that none of the series is integrated 
of order 2. Unlike the Johansen cointegration procedures, the ARDL approach is suitable for small sample size study [21]. Therefore, in order to apply the $\mathrm{F}$ test, the bounds testing modelling framework involves estimating the following equation:

$$
\begin{aligned}
\Delta \ln P P_{t}= & a_{0}+\lambda_{1} \ln P P_{t-1}+\lambda_{2} \ln G D P_{t-1}+\lambda_{3} \ln L_{t-1}+\lambda_{4} \ln F D I_{t-1}+\lambda_{5} \ln D I_{t-1} \\
& +\sum_{i=1}^{p} \phi_{i} \Delta \ln P P_{t-i}+\sum_{i=1}^{q_{1}} \psi_{i} \Delta \ln G D P_{t-i}+\sum_{i=1}^{q_{2}} \gamma_{i} \Delta \ln L_{t-i} \\
& +\sum_{i=1}^{q_{3}} \omega_{i} \Delta \ln F D I_{t-i}+\sum_{i=1}^{q_{4}} \varphi_{i} \Delta \ln D I_{t-i}+\eta D U M_{t}+\varepsilon_{t}
\end{aligned}
$$

where $\lambda_{i}$ are the long-run elasticity coefficients, $a_{0}$ the drift, $\varepsilon_{t}$ the error term and $\Delta$ is the first difference operator.

The ARDL bounds test for cointegration starts with the estimation of Equation (6) using the ordinary least square (OLS) method after selecting the optimal lag length of the model using either the Akaike Information criterion (AIC) or the Schwarz Information criterion (SIC). The F test is performed by constraining the estimated coefficients of lagged level variables equal to zero. Therefore, the null hypothesis for no cointegration between the variables of interest against the alternative is defined as:

$$
\begin{aligned}
& H_{0}: \lambda_{1}=\lambda_{2}=\lambda_{3}=\lambda_{4}=\lambda_{5}=0 \\
& H_{a}: \lambda_{1} \neq \lambda_{2} \neq \lambda_{3} \neq \lambda_{4} \neq \lambda_{5} \neq 0
\end{aligned}
$$

The test which normalizes on $\mathrm{Y}$ (dependent variable) is denoted $F_{P P}=(P P \backslash G D P, L, F D I, D I)$.

The computed F-statistics are compared to the critical bounds value reported by [21] for small sample size study. If the computed F-statistic is greater than the critical upper bound value, then the null hypothesis of no cointegration is rejected. If the computed F-statistic is lower than the critical lower bound value, then the null hypothesis is accepted. Nevertheless, when the computed F-statistic falls inside the critical lower and upper bound values, a conclusive decision cannot be made about the cointegration status without knowing the order of integration of the underlying regressors.

In the case of cointegration relationship between the variables, firstly, the ARDL $\left(p, q_{1}, q_{2}, q_{3}, q_{4}\right)$ long-run model is estimated as follows:

$$
\begin{aligned}
\ln P P_{t}= & a_{1}+\sum_{i=1}^{p} \lambda_{1} \ln P P_{t-i}+\sum_{i=1}^{q_{1}} \lambda_{2} \ln G D P_{t-i}+\sum_{i=1}^{q_{2}} \lambda_{3} \ln L_{t-i}+\sum_{i=1}^{q_{3}} \lambda_{3} \ln F D I_{t-i} \\
& +\sum_{i=1}^{q_{4}} \lambda_{4} \ln D I_{t-i}+\theta D U M_{t}+\varepsilon_{t}
\end{aligned}
$$

Second, the short-run dynamic parameters are gotten by estimating an error correction model associated with the long-run estimates. This is specified as follows:

$$
\begin{aligned}
\Delta \ln P P_{t}= & a_{2}+\sum_{i=1}^{p} \phi_{i} \Delta \ln P P+\sum_{i=1}^{q_{1}} \psi_{i} \Delta \ln G D P_{t-i}+\sum_{i=1}^{q_{2}} \gamma_{i} \Delta \ln L_{t-i}+\sum_{i=1}^{q_{3}} \omega_{i} \Delta \ln F D I_{t-i} \\
& +\sum_{i=1}^{q_{4}} \varphi_{i} \Delta \ln D I_{t-i}+\eta D U M_{t}+\rho E C T_{t-1}+\mu_{t}
\end{aligned}
$$

where $\rho$ the coefficient of the error correction term (ECT), represents the speed of adjustment of the model to the long-term equilibrium. $\phi, \psi, \gamma, \omega, \varphi$ are the short-run elasticity coefficients.

\subsection{Causality Analysis}

The standard Granger-causality test is conducted between two time series to determine whether one variable can be employed to predict another [22]. However, the methodology has some limitations. The granger test is designed to handle causality direction between two variables, so as pointed out by scholar [23], neglected the effect of other relevant variables in the estimation may produce spurious results. In addition, since, there is at least one-way causation in the case of cointegration among variables, spurious causality may be identified in the absence of long-run equilibrium relationship [23]. In order, to cope with these limitations, the study adopted the 
Toda and Yamamoto procedure [24] based on Granger-non causality model augmented with extra lags determined by the maximum order of integration of the variables of interest. The technique requires in the first stage to define the appropriate lag length $m$ for the vector autoregressive (VAR) model according to Akaike Information Criterion (AIC), or Schwarz Information Criterion (SIC) and then, select the maximum order of integration $\left(d_{\max }\right)$ for the variables in the system. In order to test for the causality the procedures recommended by [24], require estimating the following $\operatorname{VAR}\left(m+d_{\max }\right)$ model:

$$
\begin{aligned}
\ln P P_{t}= & \alpha+\sum_{i=1}^{m} \beta_{i} \ln P P_{t-i}+\sum_{i=m+1}^{m+d_{\max }} \beta_{i} \ln P P_{t-i}+\sum_{i=1}^{m} \lambda_{i} \ln G D P_{t-i} \\
& +\sum_{i=m+1}^{m+d_{\max }} \lambda_{i} \ln G D P_{t-i}+\sum_{i=1}^{m} \theta_{i} \ln L_{t-i}+\sum_{i=m+1}^{m+d_{\max }} \theta_{i} \ln L_{t-i}+\sum_{i=1}^{m} \eta_{i} \ln F D I_{t-i} \\
& +\sum_{i=m+1}^{m+d_{\max }} \eta_{i} \ln F D I_{t-i}+\sum_{i=1}^{m} \varphi_{i} \ln D I_{t-i}+\sum_{i=m+1}^{m+d_{\max }} \varphi_{i} \ln D I_{i-1}+\varepsilon_{t}
\end{aligned}
$$

where all variables are as previously defined. $\alpha, \beta_{i}, \lambda_{i}, \theta_{i}, \eta_{i}$ and $\varphi_{i}$ are parameters of the model and the residual. We estimated Equation (9) considering each of the variables in turn as the dependent variable. We expressed the null hypothesis of no causal relationship against the alternative of presence of causality with respect to the system equations. When $\ln P P$ is the dependent variable in the VAR system as specified in Equation (9), the null hypothesis of no causal relationship from $\ln G D P$ to $\ln P P$, from $\ln L$ to $\ln P P$, from $\ln F D I$ to $\ln P P$, from $\ln D I$ to $\ln P P$ involve that $\lambda_{i}=0, \theta_{i}=0, \eta_{i}=0$ and $\varphi_{i}=0$ respectively.

\section{Empirical Results}

\subsection{Cointegration}

Before performing, the cointegration test, we examined the order of integration of the time series by using the Augmented Dicker fuller (ADF) unit root test to ensure that none of the variables is stationary at second difference and then avoid spurious results. The results summarized in Table 1 reveal that all the variables are integrated of order one, implying that the ARDL bounds test for cointegration is valid. The ARDL bounds testing procedure is conducted considering each variable as a dependent variable in the ARDL-OLS regressions.

As proposed by researcher [25], a maximum of 2 lags is selected for our annual data. The bounds test results are given in Table 2. When Port production output is the dependent variable, the computed F-statistics, 6.056311, is higher than the upper bound critical value 5.650 at $1 \%$ level. Furthermore, when economy performance is the dependent variable, the F-statistic computed, 4.814617 is higher than the upper bound critical value 4.117 at $5 \%$ level. Hence, the null hypotheses of no cointegration are rejected. These findings indicate that there exist long run relationship between the variables when the regressions are normalized on both Port and economy performance.

In line with the production function developed for this study, we selected Port production output as the dependent variable. Having determined the existence of cointegration relationship between port, economy performance, foreign direct investment, domestic investment and labor, we estimated the long-run and the short-run parameters. The estimated long-run coefficients by normalizing on port are presented in Table 3 . In the long run, domestic investment has a positive and significant impact on port production. A percentage increase in domestic investment has contributed to about $0.35 \%$ increase in port growth all things being equal. However, the Longterm coefficients for other variables namely economy performance, foreign direct investment, labor force and political instability dummy were found statistically insignificant within the conventional $1 \%-10 \%$ t-probability.

The short-run elasticity coefficients associated with the long-run relationships are estimated using an error correction model (ECM). The estimated results are reported in Table 4. The error correction term (ECT) coefficient estimated $(-0.73)$ is highly significant at $1 \%$ level with the expected sign and indicates a high speed of adjustment to long-run equilibrium after a shock. This implies that almost $73 \%$ of disequilibrium caused by the previous year's shock is adjusted back to the long-run equilibrium in the current year. The short-run lag-one and lag-two coefficients of foreign direct investment are significant at $5 \%$ and $1 \%$ level respectively, although the Long-term coefficient was found not significant. The contribution from FDI is about $0.06 \%$ in the short-run lagone period and short-run lag-two period elasticity is $0.09 \%$. 
Table 1. Augmented Dicker-Fuller unit root test results.

\begin{tabular}{|c|c|c|c|c|c|}
\hline \multirow{2}{*}{ Series } & \multirow{2}{*}{ ADF Test Value } & \multicolumn{3}{|c|}{ Critical Value } & \multirow{2}{*}{ Outcome } \\
\hline & & $1 \%$ & $5 \%$ & $10 \%$ & \\
\hline $\ln P P$ & -1.935843 & -4.262735 & -3.552973 & -3.209642 & Non stationary \\
\hline$\Delta \ln P P$ & $-5.481082^{* * *}$ & -4.273277 & -3.557759 & -3.212361 & Stationary \\
\hline $\operatorname{lnGDP}$ & -2.883426 & -4.273277 & -3.557759 & -3.212361 & Non stationary \\
\hline$\Delta \operatorname{lnGDP}$ & $-3.773876^{* *}$ & -4.273277 & -3.557759 & -3.212361 & Stationary \\
\hline $\operatorname{lnFDI}$ & -1.550299 & -3.646342 & -2.954021 & -2.615817 & Non stationary \\
\hline$\Delta \operatorname{lnFDI}$ & $-3.304325^{* *}$ & -3.699871 & -2.976263 & -2.627420 & Stationary \\
\hline $\operatorname{lnDI}$ & -2.975691 & -4.296729 & -3.568379 & -3.218382 & Non stationary \\
\hline$\Delta \operatorname{lnDI}$ & $-4.983489^{* * *}$ & -4.273277 & -3.557759 & -3.212361 & Stationary \\
\hline $\ln L$ & 1.058008 & -4.356068 & -3.595026 & -3.233456 & Non stationary \\
\hline$\Delta \ln L$ & $-5.261270^{* * *}$ & -4.356068 & -3.595026 & -3.233456 & Stationary \\
\hline
\end{tabular}

Notes: $\Delta$ first difference operator. ${ }^{* * *}\left({ }^{* *}\right)$ denote rejection of the null hypothesis of unit root at $1 \%$ and $5 \%$ level of significance.

Table 2. Bounds test results for cointegration relationship.

\begin{tabular}{ccc}
\hline Dependent variable & F-Statistic & Outcome \\
\hline$F_{P P}($ PP\GDP FDI DI L) & 6.056311 & Cointegration \\
$F_{G D P}($ GDP\PP FDI DI L) & 4.814617 & Cointegration \\
$F_{F D I}$ (FDI $\backslash G D P$ PP DI L) & 3.805014 & No cointegration \\
$F_{D I}$ (DIIFDI GDP PP L) & 3.434352 & No cointegration \\
$F_{L}($ LIDI FDI GDP PP) & 3.975338 & No cointegration \\
\hline
\end{tabular}

Notes: Asymptotic critical value bounds are obtained from appendix A1, A2 case II of [21]: Intercept and no trend for $\mathrm{k}=4$ and $\mathrm{N}=34$. Lower bound I $(0)=4.165$ (2.957) and Upper bound $=5.650(4.117)$ at $1 \%(5 \%)$ significance level.

Table 3. Estimated long-run (ARDL) coefficients.

\begin{tabular}{cccc}
\hline Dependent variable: PP & & & \\
\hline Regressor & Coefficient & t-statistic & p-value \\
\hline C & -6.150687 & -0.916732 & 0.3671 \\
lnGDP & 0.686518 & 1.339352 & 0.1912 \\
$\operatorname{lnFDI}$ & 0.003237 & 0.112147 & 0.9115 \\
$\operatorname{lnDI}$ & 0.353696 & $3.426324^{* * *}$ & 0.0019 \\
$\operatorname{lnL}$ & 0.352969 & 1.365845 & 0.1829 \\
DUM & 0.034579 & 0.754082 & 0.4571 \\
\hline
\end{tabular}

Notes: ${ }^{* * *}$ denotes $1 \%$ significance level.

Moreover, in the short-run lag-2 period, the estimated elasticity of economy performance $(-1.75 \%)$ and labor $(-14.91 \%)$ are negatively signed and statistically significant at $1 \%$ and $10 \%$ level respectively, whereas economy performance and labor force were not statistically significant in the long run.

The results of the diagnostic test applied on the ECM model, given in Table 5, illustrate that the model passes the Jarque-Bera normality test and there are no evidence of serial correlation and heteroscedasticity at $5 \%$ level. 
Table 4. Error correction estimates of port production model.

\begin{tabular}{|c|c|c|c|}
\hline Dependent variable: & & & \\
\hline Regressor & Coefficient & t-statistic & $\mathrm{p}$-value \\
\hline $\mathrm{C}$ & 0.165207 & $3.143295^{* * *}$ & 0.0056 \\
\hline$\Delta \ln \mathrm{PP}(-1)$ & 0.231585 & 1.241298 & 0.2304 \\
\hline$\Delta \ln P P(-2)$ & 0.277367 & 1.394186 & 0.1802 \\
\hline$\Delta \operatorname{lnGDP}(-1)$ & -0.188843 & -0.480325 & 0.6368 \\
\hline$\Delta \operatorname{lnGDP}(-2)$ & -1.746916 & $-3.527284^{* * *}$ & 0.0024 \\
\hline$\Delta \operatorname{lnFDI}(-1)$ & 0.056514 & $2.339136^{* *}$ & 0.0311 \\
\hline$\Delta \operatorname{lnFDI}(-2)$ & 0.091351 & $4.003048^{* * *}$ & 0.0008 \\
\hline${ }^{*} \Delta \operatorname{lnDI}(-1)$ & -0.250477 & $-2.305995^{* *}$ & 0.0332 \\
\hline$\Delta \operatorname{lnDI}(-2)$ & -0.108604 & -0.931537 & 0.3639 \\
\hline$\Delta \operatorname{lnL}(-1)$ & 10.76905 & 1.461249 & 0.1612 \\
\hline$\Delta \operatorname{lnL}(-2)$ & -14.90607 & $-2.054093^{*}$ & 0.0548 \\
\hline DUM & -0.025958 & -0.644574 & 0.5273 \\
\hline $\mathrm{ECT}(-1)$ & -0.727846 & $-4.078313^{* * *}$ & 0.0007 \\
\hline
\end{tabular}

R-squared $=0.702625$ Adjusted R-square $=0.504374$ F-statistic $=3.544128$ Prob $($ F-statistic $)=0.007780$ D-W statistic $=2.320042$

Notes: $\Delta$ first difference operator. ${ }^{* * *}\left({ }^{* *}\right){ }^{*}$ significance at $1 \%, 5 \%$ and $10 \%$ level.

Table 5. Diagnostic tests from the ARDL error correction model.

\begin{tabular}{ccc}
\hline Null hypothesis & Test statistics & p-value \\
\hline No serial correlation & 3.515131 & 0.172464 \\
Normality & 1.276156 & 0.528307 \\
Homoscedasticity & 27.94618 & 0.217824 \\
No mis-specification & 1.113636 & 0.352522 \\
\hline
\end{tabular}

The cumulative sum of recursive residual (CUSUM) and of squares residual (CUSUMQ) plot displayed in Figure 1, shows the stability of the parameters of the ECM model over the sample period. The red lines denote critical bounds at 5\% significance level.

\subsection{Causality Test Results}

The empirical results of Toda-Yamamoto Granger non-causality test are summarized in Table 6. The estimated results indicate that there is bidirectional causality between port and economy performance. Similarly, a reciprocal causal relationship exists between port and foreign direct investment. The causations running from port to economy performance, from economy performance to port, from port to FDI and from FDI to port are determined at the $10 \%(\chi=7.44), 1 \%(\chi=15.18), 10 \%(\chi=7.04)$ and $10 \%(\chi=6.79)$ levels of significance respectively. On the other hand, there is one-way causal effect going from domestic investment to port, from economy performance to FDI, from FDI to domestic investment, from labor force to port, from labor force to economy. performance and from labor force to FDI found at 5\% $(\chi=10.26), 10 \%(\chi=6.30), 5 \%(\chi=8.48), 1 \%(\chi=$ $17.11) ; 1 \%(\chi=24.84)$ and $1 \%(\chi=14.74)$ level respectively. Since there is non-causality running from the other variables to labor force, the results has been dropped from Table 6.

\section{Conclusion and Policy Implications}

In this paper, econometric approaches have been used to investigate the long-run and causal relationships between 

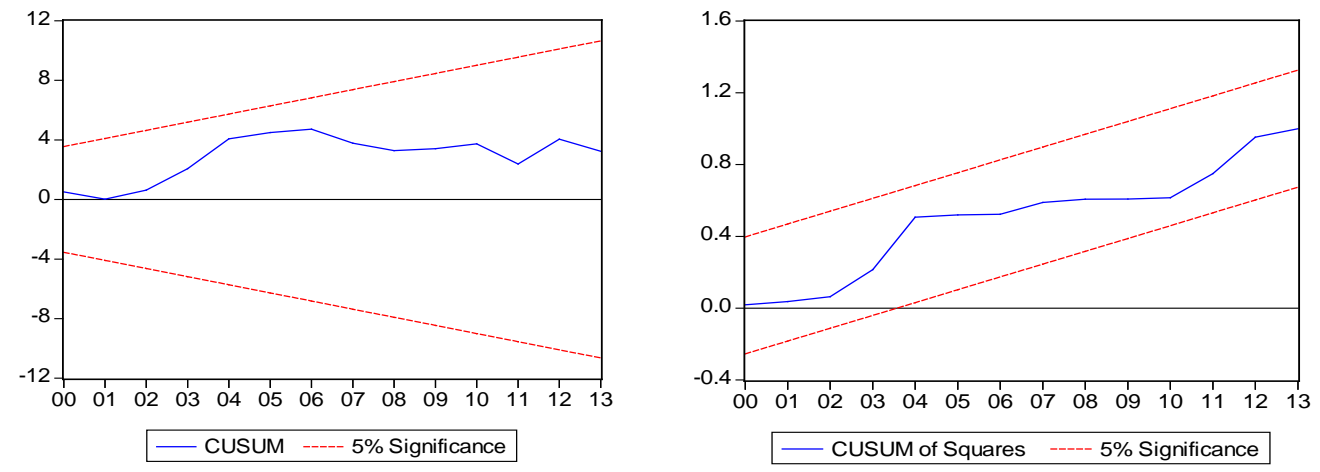

Figure 1. Plot of CUSUM and CUSUMQ for coefficients for ARDL ECM model.

Table 6. Toda-Yamamoto Granger non-causality test results.

\begin{tabular}{|c|c|c|c|}
\hline Dependent variable & Excluded variables & Chi-Square & p-value \\
\hline \multirow{5}{*}{$\ln P P$} & $\operatorname{lnGDP}$ & 15.17814 & $0.0017^{* * *}$ \\
\hline & $\operatorname{lnFDI}$ & 6.789841 & $0.0789^{*}$ \\
\hline & $\operatorname{lnDI}$ & 10.25707 & $0.0165^{* *}$ \\
\hline & $\ln L$ & 17.11023 & $0.0010^{* * *}$ \\
\hline & All value taken together & 60.52966 & 0.0085 \\
\hline \multirow{5}{*}{$\operatorname{lnGDP}$} & $\ln P P$ & 7.440089 & $0.0591^{*}$ \\
\hline & $\operatorname{lnFDI}$ & 4.859076 & 0.1824 \\
\hline & $\operatorname{lnDI}$ & 1.507420 & 0.6806 \\
\hline & $\ln L$ & 24.84314 & $0.0000^{* * *}$ \\
\hline & All value taken together & 40.22370 & 0.0001 \\
\hline \multirow{5}{*}{$\operatorname{lnFDI}$} & $\operatorname{lnGDP}$ & 6.303205 & $0.0978^{*}$ \\
\hline & $\ln P P$ & 7.039671 & $0.0706^{*}$ \\
\hline & $\operatorname{lnDI}$ & 3.277839 & 0.3507 \\
\hline & $\ln L$ & 14.74045 & $0.0021^{* * *}$ \\
\hline & All value taken together & 34.54035 & 0.0006 \\
\hline \multirow{5}{*}{$\operatorname{lnDI}$} & $\operatorname{lnGDP}$ & 6.144913 & 0.1048 \\
\hline & $\operatorname{lnFDI}$ & 8.478563 & $0.0371^{* *}$ \\
\hline & $\ln P P$ & 3.318796 & 0.3450 \\
\hline & $\ln L$ & 2.505887 & 0.4742 \\
\hline & All value taken together & 49.47809 & 0.0000 \\
\hline
\end{tabular}

Notes: ${ }^{* * *}\left({ }^{* *}\right){ }^{*}$ indicate the rejection of null hypothesis (no causality) at $1 \%, 5 \%$ and $10 \%$ significance level.

economy performance, foreign direct investment, domestic investment and port sector productivity in Ivorian context over the period of 1980-2013.

The study used the bounds testing (ARDL) approach for cointegration to determine the long-run and short-run relationships between the variables of interest. The Bounds test results imply that there is a long-term relationship between the variables of the study when port production output is adopted as dependent variable (normalized). In addition, it is found that domestic investment has a long-term effect on port productivity. Conversely, 
foreign direct investment and Economy performance do not have a long-term impact on port production, but their estimated short-term coefficients provide evidence of short-run effects. The negative sign of short-run lag-two period of GDP reveals the overcapacity issues facing by Ivorian port sector. The relatively poor infrastructures conditions of port sector in Cote d'Ivoire impede its supply capacity regarding the growing demand from the economy performance. Nevertheless, foreign participation positively influences port productivity in the short run, confirming the potential role of FDI in enhancing productivity.

Consequently, Toda-Yamamoto causality approach has been applied to explore the direction of causation among the variables. The findings obtained from the causality test indicate evidence of reciprocal causality relation among port and economy performance and on the other hand, between port and FDI. Moreover, there is unidirectional causation going from domestic investment to port, from economy performance to FDI, from FDI to domestic investment, from labor force to port, from labor force to economy performance and from labor force to FDI.

The empirical results show that economy performance, foreign direct investment and domestic investment are important in explaining port sector growth in Ivory Coast. Therefore, the study suggests focusing on investment strategies that involve private (foreign and domestic) participation in projects dedicated to improve the safety, quality of operations in the port sector and to boost transport connectivity.

\section{References}

[1] Eberts, R. (2000) Understanding the Impact of Transportation on Economic Development. In: Transportation Research Board Conference, Transportation in the New Millennium, Vol. 30, p. 2000. http://trid.trb.org/view.aspx?id=639428

[2] Moon, S.H. (1995) Port Economic Impact Model (PIM) and Its Planning Applications. Maritime Policy and Management, 22, 363-387. http://dx.doi.org/10.1080/03088839500000072

[3] Siegesmund, P., Kruse, C.J., Prozzi, J.P., Alsup, R. and Harrison, R. (2008) Guide to the Economic Value of Texas Ports. No. 0-5538-P1. http://trid.trb.org/view.aspx?id=902265

[4] World Bank (2013) Cote d’Ivoire-Joint Staff Advisory Note on the National Development Plan 2012-15. World Bank, Washington DC.

[5] Findley, D.J., Small, P.J.D., Tran, W., Heller, A., Bert, S.A., Searcy, S.E. and Hall Jr., W.W. (2011) Economic Contribution of the North Carolina Ports.

http://www.ncports.com/elements/media/files/economic-contribution-north-carolina-ports.pdf

[6] Ducruet, C. (2009) Port Regions and Globalization. Ports in Proximity: Competition and Coordination among Adjacent Seaports, 41-53.

[7] Vanoutrive, T. (2010) Exploring the Link between Port Throughput and Economic Activity: Some Comments on Space- and Time-Related Issues. In: 50th European Congress of the Regional Science Association International (ERSA Congress 2010): Sustainable Regional Growth and Development in the Creative Knowledge Economy, European Regional Science Association (ERSA), Belgium. http://biblio.ugent.be/publication/1055541/file/1055542

[8] Breidenbach, P. and Mitze, T. (2013) The Long Shadow of Port Infrastructure in Germany-Cause or Consequence of Regional Prosperity? Available at SSRN 2302667.

[9] Rodrigue, J.P. (2010) Maritime Transportation: Drivers for the Shipping and Port Industries. In: International Transport Forumon Transport and Innovation: Unleashing the Potential, Leipzig, 26-28 May, Forum Paper 2, 23 p.

[10] Tukan, M., Achmadi, T. and Widjaya, S. (2012) Selection of Pilot Ports and Effect of Long Dock Investments to Economic Growth an Island. Academic Research International ISSN-L, 2223-9553.

[11] Zhang, G.Q., Zhang, N. and Wang, Q.Y. (2005) Container Ports Development and Regional Economic Growth: An Empirical Research on the Pearl River Delta Region of China. Proceedings of the Eastern Asia Society for Transportation Studies, 5, 2136-2150.

[12] Cheung, S.M.S. and Yip, T.L. (2009) Analysis on Port-City Growths in China. International Forum on Shipping, Ports and Airports (IFSPA) 2009-Post-Financial Tsunami: The Way Forward for Shipping, Transport and International Trade, Hong Kong, 24-27 May 2009, 47-53.

[13] Foster, V. and Pushak, N. (2011) Cote d'Ivoire’s Infrastructure: A Continental Perspective. World Bank Policy Research Working Paper Series, Washington DC.

[14] UNCTAD (2011) Best Practices in Investment for Development How to Utilize FDI to Improve Transport Infrastructure-Ports: Lessons from Nigeria. UNCTAD/DIAE/PCB/8, United Nations, ISBN 978-92-1-112794-2.

[15] Khawar, M. (2003) Productivity and Foreign Direct Investment-Evidence from Mexico. Journal of Economic Studies, 
30, 66-76. http://dx.doi.org/10.1108/014435803104552778

[16] Aitken, B.J. and Harrison, A.E. (1999) Do Domestic Firms Benefit from Direct Foreign Investment? Evidence from Venezuela. American Economic Review, 89, 605-618. http://dx.doi.org/10.1257/aer.89.3.605

[17] Pradhan, R.P. and Bagchi, T.P. (2013) Effect of Transportation Infrastructure on Economic Growth in India: The VECM Approach. Research in Transportation Economics, 38, 139-148. http://dx.doi.org/10.1016/j.retrec.2012.05.008

[18] Deng, T. (2013) Impacts of Transport Infrastructure on Productivity and Economic Growth: Recent Advances and Research Challenges. Transport Reviews: A Transnational Transdisciplinary Journal, 33, 686-699.

[19] Pesaran, M.H., Shin, Y. and Smith, R.J. (2001) Bounds Testing Approaches to the Analysis of Level Relationships. Journal of Applied Econometrics, 16, 289-326. http://dx.doi.org/10.1002/jae.616

[20] Johansen, S. and Juselius, K. (1990) Maximum Likelihood Estimation and Inference on Cointegration-With Applications to the Demand for Money. Oxford Bulletin of Economics and Statistics, 52, 169-210. http://dx.doi.org/10.1111/j.1468-0084.1990.mp52002003.x

[21] Narayan, P.K. (2004) Reformulating Critical Values for the Bounds F-Statistics Approach to Cointegration: An Application to the Tourism Demand Model for Fiji. Department of Economics, Discussion Papers, No.02/04, Monash University, Victoria 3800, Australia.

[22] Granger, C.W. (1980) Testing for Causality: A Personal Viewpoint. Journal of Economic Dynamics and Control, 2, 329-352. http://dx.doi.org/10.1016/0165-1889(80)90069-X

[23] Maddala, G.S. (2001) Introduction to Econometrics. 3rd Edition, John Wiley and Sons, Inc., Hoboken.

[24] Toda, H.Y. and Yamamoto, T. (1995) Statistical Inference in Vector Autoregressions with Possibly Integrated Processes. Journal of Econometrics, 66, 225-250. http://dx.doi.org/10.1016/0304-4076(94)01616-8

[25] Pesaran, M.H. and Shin, Y. (1998) An Autoregressive Distributed-Lag Modelling Approach to Cointegration Analysis. Econometrics and Economic Theory in the 20th Century: The Ragnar Frisch Centennial Symposium, 31, 371-413. http://dx.doi.org/10.1017/CCOL0521633230.011 